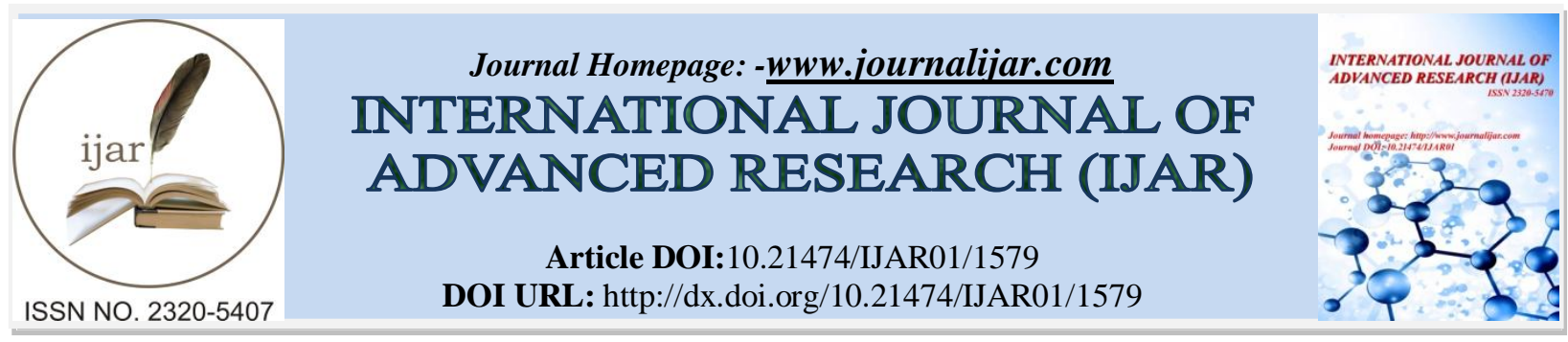

RESEARCH ARTICLE

\title{
INVESTIGATIONS ON BLOOD ENZYME ACTIVITIES IN COWS WITH SUBCLINICAL AND CLINICAL KETOSIS.
}

Vania Marutsova.

Department of Internal Diseases, Faculty of Veterinary Medicine, Trakia University, Stara Zagora, Bulgaria

\section{Manuscript Info}

Manuscript History

Received: 12 July 2016

Final Accepted: 16 August 2016

Published: September 2016

Key words:-

subclinical ketosis, clinical ketosis, $\beta$ -

hydroxybutyrate, enzymes, dairy cows

\section{Abstract}

Ketosis is a common metabolic disease in high-yielding dairy cows incurring substantial economic losses to cattle husbandry. The present study was performed on 157 Holstein cows with yearly milk yield of $9000-11000 \mathrm{~L}$, in their $1^{\text {st }}$ to $4^{\text {th }}$ lactation and average body weight 450-550 kg. The animals were divided into 3 groups: first group pregnant cows (from day 15 to day 0 pre-calving); second group recently calved (from day 0 to day 15 postpartum) and third group lactating (from day 30 to 45 postpartum). Blood concentrations of $\beta$ hydroxybutyric acid (BHBA) were assayed in all cows and on the basis of results, they were classifies as healthy (control, C), affected with subclinical ketosis (SCK) and clinical ketosis (CK). Blood enzyme activities of Aspartate aminotransferase (ASAT, U/l), Alanine aminotransferase (ALAT, U/l), Lactate dehydrogenase (LDH, U/l), Creatine kinase (CK, U/l), $\gamma$-glutamyltransferase (GGT, U/l) and Alkaline phosphatase (AP, U/1) were determined. The results indicated that pregnant cows from group I were affected with subclinical, not clinical ketosis (BHBA $<2.6 \mathrm{mmol} / \mathrm{l}$ ). After calving and in the period of lactation (groups II and III), cows suffered from both forms of ketosis. Blood biochemical analysis of activities of ASAT, ALAT, LDH, AP, CK and GGT demonstrated a various extent of statistically significant hyperenzymemia in SCK and CK, corresponding to the severity of cell damage of parenchymal organs.

Copy Right, IJAR, 2016,. All rights reserved.

\section{Introduction:-}

In cows, ketosis is most commonly encountered by the end of pregnancy and early lactation (2-6 weeks postpartum), affecting animals at 5 to 8 years of age. The disease increased culling rates from 20 to $30 \%$, not because of fatal outcomes, but due to low milk yield and reproductive failure (McArt et al., 2013; Suthar et al., 2013; Santschi et al., 2014), metritis and mastitis (Suriyasathaporn et al., 2000), abomasal displacement (Chapinal et al., 2012) or development of CK (Duffield et al., 2009). A more frequent problem in high-yielding cows is SCK. On the average, about $40 \%$ of dairy cows have suffered from SCK at least once during a lactation (Asl et al., 2011; McArt et al., 2012), while clinical ketosis is encountered in about 5\% of the population (Kelton et al., 1998).

Blood biochemical analysis results indicative for impaired metabolic status in cows with SCK and CK are contradictory and incomplete. Kauppinen (1983) reported that in dairy cows, high milk yield correlated to high blood BHBA concentrations and predisposed to development of ketosis. In ketosis, ketone bodies are synthesized in 
the liver from free fatty acids and then enter the circulation. A number of authors (Herdt, 2000; Oetzel, 2007) outlined that blood BHBA levels were indicative for the severity of negative energy balance (NEB) and the rate of lipolysis in dairy cows. Bovine blood BHBA concentrations up to $1.2 \mathrm{mmol} / \mathrm{l}$ are considered normal; from 1.2 to 2.6 mmol/l - indicate SCK and over $2.6 \mathrm{mmol} / \mathrm{l}$ - CK (Seifi et al., 2011; González et al., 2011; McArt et al., 2013).

Sahinduran et al. (2010); Joksimović and Davidović (2012); Djoković et al. (2013) and Simonov and Vlizlo (2015) established increased activity of ASAT, ALAT, GGT and AP in dairy cows with SCK and CK during pregnancy and lactation periods consequently to impaired liver function. Sahinduran et al. (2010) reported a positive correlation between blood ASAT and GGT, as well as between blood GGT and BHBA in cows with ketonaemia. Some researchers (Peneva and Goranov, 1984) detected low blood AP and high ASAT, ALAT and LDH in ketotic cows, others (Joksimović and Davidović, 2012) - increased activity of GGT, while thirds (Djoković et al., 2013) demonstrated higher blood ASAT and GGT reduction in lactating cows with ketosis and fatty liver dystrophy. Sorbitol dehydrogenase (SDH) and GGT could be used as prognostic markers for ketosis in ruminants instead of LDH and AP (Wierda et al., 1985). Significantly elevated activities of these enzymes in blood were reported in a previous study of ours (Marutsova, 2015) in sheep with SCK and CK.

Contrary to aforementioned findings, no statistically significant changes in blood ASAT and ALAT in ketosis were reported (Rezapour and Taghinejad-Roudbaneh, 2011; Anoushepour et al., 2014).

The main purpose of the present study was to establish the changes in blood BHBA and enzyme activities of ASAT, ALAT, CK, GGT, LDH and AP in cows with subclinical and clinical ketosis.

\section{Material and Methods:-}

\section{Animals:-}

The present study was performed on 157 Holstein cows with yearly milk yield of $9000-11000 \mathrm{~L}$, in their $1^{\text {st }}$ to $4^{\text {th }}$ lactation and average body weight $450-550 \mathrm{~kg}$.

\section{Experimental design:-}

The cows were divided into 3 groups according to their physiological condition: first group - pregnant cows (from day 15 to day 0 pre-calving); second group - recently calved (from day 0 to 15 postpartum) and third group lactating (from day 30 to 45 postpartum). Blood concentrations of $\beta$-hydroxybutyric acid (BHBA) were assayed in all cows and on the basis of results, they were classifies as healthy (control, BHBA $<1.2 \mathrm{mmol} / \mathrm{l}$ ), affected with SCK (BHBA from 1.2 to $2.6 \mathrm{mmol} / \mathrm{l})$ and $\mathrm{CK}(\mathrm{BHBA}>2.6 \mathrm{mmol} / \mathrm{l})$.

The first group included 21 pregnant cows (9 healthy; 12 or 57\% - with SCK). Blood BHBA concentrations indicative for clinical ketosis were not established in this group. The second group comprised 90 recently calved cows - 55 healthy (control), 27 (30\%) with SCK and 8 (8.88\%) with CK. The third group (47 lactating cows) included 24 healthy (control) cows; 15 animals (32\%) affected with SCK and 8 (17\%) - with CK.

All cows included in this field study were treated against parasites. They were reared in premises under conditions according to the species and in compliance with animal welfare requirements and regulations.

\section{Blood samples and analyses:-}

Blood samples were collected through puncture of the coccygeal vein using sterile $21 \mathrm{G}$ needles and vacutainers with heparin (Biomed, Bulgaria). Samples were obtained in the morning before feeding and were stored and transported at $4^{0} \mathrm{C}$. Analysis was performed within 24 hours after sampling. Blood BHBA concentrations were determined in situ using a portable Xpress-I system (Nova Biomedical, UK). The following indices were determined: Aspartate aminotransferase (ASAT, U/l), Alanine aminotransferase (ALAT, U/l), Lactate dehydrogenase (LDH, U/l), Alkaline phosphatase (AP, U/l), Creatine kinase (CK, U/l) and $\gamma$-glutamyltransferase (GGT, U/l). The biochemical tests were performed using colorimetric method (IFCC $37^{\circ}$ ) with test Biolab Diagnostics (France) on an automated biochemical analyserMindray BS-120 (China).

\section{Statistical analysis:-}

Statistical analysis was done with Statistica 6.0, ANOVA test and StatSoft, Inc. (USA, 1993). Results were presented as mean $(x) \pm$ standard deviation $(\mathrm{SD})$. The level of statistically significance was $\mathrm{p}<0.05$. 


\section{Results:-}

Blood biochemical analysis of control animals (pregnant, recently calved and lactating) showed average BHBA concentrations of $0.52 \pm 0.09 \mathrm{mmol} / \mathrm{l}, 0.43 \pm 0.25 \mathrm{mmol} / \mathrm{l}$ and $0.30 \pm 0.16 \mathrm{mmol} / \mathrm{l}$ respectively (Fig. 1 ).

In cows from the first group with SCK, blood BHBA increased substantially to $1.65 \pm 0.63 \mathrm{mmol} / \mathrm{l}$ as compared to control group $(0.52 \pm 0.09 \mathrm{mmol} / \mathrm{l} ; \mathrm{p}<0.001)$; in the second group with SCK BHBA levels were $1.73 \pm 0.61 \mathrm{mmol} / 1 \mathrm{vs}$ $0.43 \pm 0.25 \mathrm{mmol} / 1$ in controls $(\mathrm{p}<0.001)$, whereas in the third group $-1.57 \pm 0.55 \mathrm{mmol} / 1(0.30 \pm 0.16 \mathrm{mmol} / 1$ in controls, $\mathrm{p}<0.05$ ) (Fig. 1).

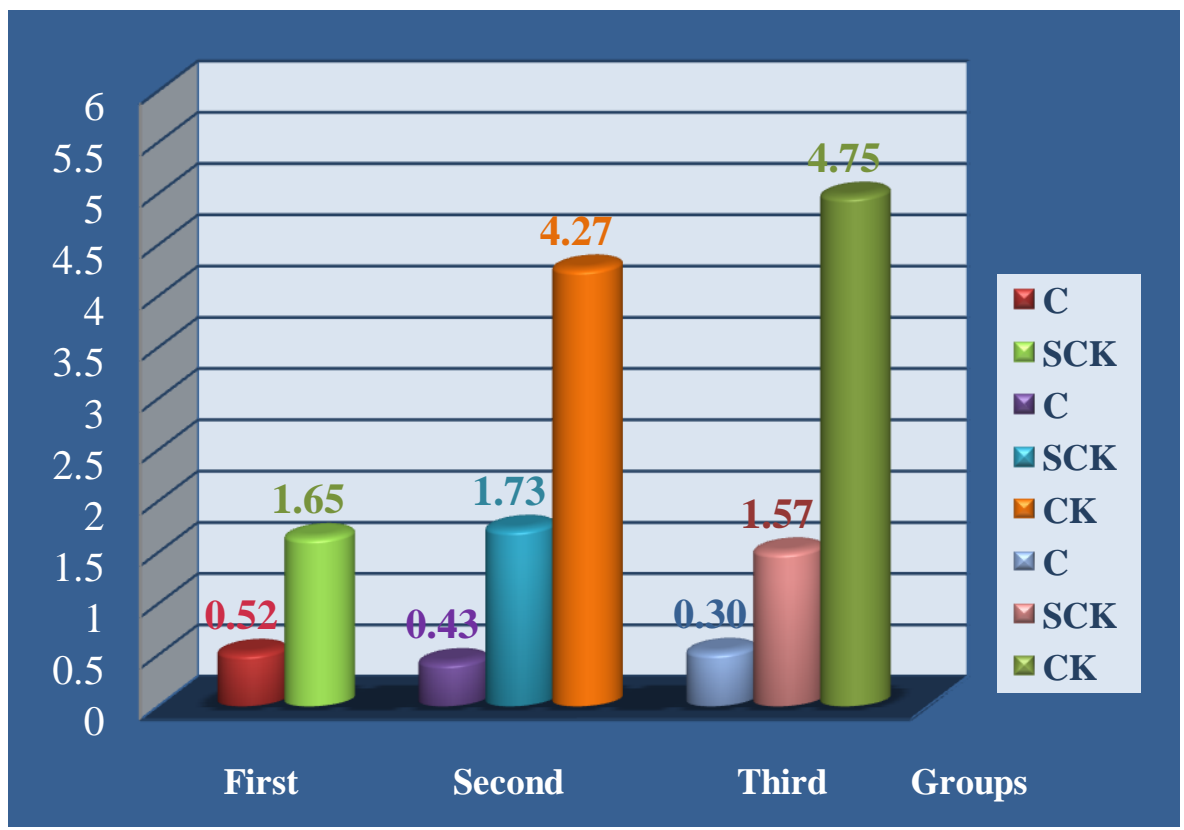

Legend: $C$-control group; $S C K$ - with subclinical ketosis; $C K$ - with clinical ketosis

Fig. 1:- Changes in blood $\beta$-hydroxybutyrate (BHBA) levels in cows from groups I, II and III with subclinical and clinical ketosis.

In cows from groups II and III with CK signs, blood BHBA was statistically significantly elevated than control group values $(0.43 \pm 0.25 \mathrm{mmol} / \mathrm{l}$ in group II and $0.30 \pm 0.16 \mathrm{mmol} / \mathrm{l}$ in group III) as well as vs values in animals with SCK (4.27 $\pm 1.29 \mathrm{mmol} / \mathrm{l}, \mathrm{p}<0.001$ and $4.75 \pm 1.36 \mathrm{mmol} / \mathrm{l}, \mathrm{p}<0.001$ respectively) (Fig. 1). There were no BHBA values $>2.6 \mathrm{mmol} / \mathrm{l}$, e.g. clinical ketosis in cows from the first group.

The analysis of blood ASAT, ALAT, LDH, AP, CK and GGT enzyme constellation in the three groups of cows with different physiological state (Table 1) showed values close to reference values: $93.50 \pm 2.0 \mathrm{U} / 1$ - ASAT; $18.27 \pm 2.2$

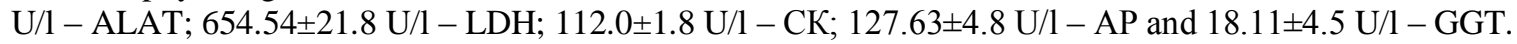

In the second control group, blood ASAT averaged 105.11 $\pm 1.6 \mathrm{U} / \mathrm{l}$, ALAT $-21.44 \pm 1.6 \mathrm{U} / \mathrm{l}, \mathrm{LDH}-817.77 \pm 23.0$ $\mathrm{U} / 1, \mathrm{CK}-171.88 \pm 8.8 \mathrm{U} / 1, \mathrm{AP}-105.57 \pm 3.0 \mathrm{U} / \mathrm{l}$ and GGT $-15.60 \pm 4.3 \mathrm{U} / \mathrm{l}$. The results in the third group of healthy controls exhibited similar values: 108.34 $\pm 5.6 \mathrm{U} / 1$ (ASAT); 22.81 $\pm 2.7 \mathrm{U} / 1$ (ALAT); 828.15 \pm 21.1 U/l (LDH); $148.37 \pm 1.2 \mathrm{U} / 1(\mathrm{CK}) ; 107.96 \pm 3.9 \mathrm{U} / 1$ (AP) and 13.92 $\pm 3.3 \mathrm{U} / 1$ for GGT (Table 1).

In cows with SCK from group I, the blood activities of LDH and GGT increased considerably vs control cows and

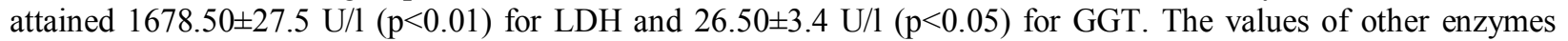
(ASAT, ALAT, CK and AP) varied within the respective reference ranges.

In cows from the second group with SCK, the activities of all studied enzymes increased significantly vs controls and measured 167.42 $\pm 4.9 \mathrm{U} / 1(\mathrm{p}<0.05)$ for ASAT; $41.14 \pm 1.7 \mathrm{U} / 1(\mathrm{p}<0.05)$ for ALAT; $2028.14 \pm 20.1 \mathrm{U} / \mathrm{l}(\mathrm{p}<0.01)$ for $\mathrm{LDH} ; 331.0 \pm 5.2 \mathrm{U} / 1(\mathrm{p}<0.05)$ for $\mathrm{CK} ; 134.22 \pm 5.1 \mathrm{U} / 1(\mathrm{p}<0.05)$ for AP и $34.71 \pm 4.8 \mathrm{U} / 1(\mathrm{p}<0.05)$ for GGT (Table 1$)$. In cows with SCK from the lactating group III, the tendency towards hyperenzymemias waspreserved: ASAT - 
139.06 $\pm 5.8 \mathrm{U} / 1(\mathrm{p}<0.05) ;$ ALAT $-43.56 \pm 3.5 \mathrm{U} / 1(\mathrm{p}<0.05) ; \mathrm{LDH}-2196.48 \pm 18.3 \mathrm{U} / 1(\mathrm{p}<0.01) ; \mathrm{CK}-191.87 \pm 4.3$ $\mathrm{U} / 1 ; \mathrm{AP}-130.37 \pm 4.0 \mathrm{U} / 1$ and GGT $-26.34 \pm 2.5 \mathrm{U} / 1(\mathrm{p}<0.05)($ Table 1$)$.

Table 1:- Changes in blood enzyme activities of Aspartate aminotransferase (ASAT, U/l), Alanine aminotransferase (ALAT, U/l), Lactate dehydrogenase (LDH, U/l), Alkaline phosphatase (AP, U/1), Creatine kinase (CK, U/l) and $\gamma$ glutamyltransferase (GGT, U/l) in cows from groups I, II and III with SCK and CK. Results are expressed as average mean \pm standard deviation.

\begin{tabular}{|c|c|c|c|c|c|c|c|c|}
\hline \multirow{3}{*}{$\begin{array}{c}\text { Parameters } \\
\text { Groups }\end{array}$} & \multicolumn{8}{|c|}{ Study period (days) } \\
\hline & \multicolumn{2}{|c|}{$\begin{array}{c}\text { Group 1 } \\
\text { (15-0 days pre-partum) }\end{array}$} & \multicolumn{3}{|c|}{$\begin{array}{c}\text { Group 2 } \\
\text { (0-15 days postpartum) }\end{array}$} & \multicolumn{3}{|c|}{$\begin{array}{c}\text { Group 3 } \\
\text { (30-45 days postpartum) }\end{array}$} \\
\hline & $C$ & $S C K$ & C & $S C K$ & $C K$ & C & $S C K$ & $C K$ \\
\hline ASAT (U/I) & $\begin{array}{l}93.50 \\
\pm 2.0\end{array}$ & $\begin{array}{c}96.36 \\
\pm 1.8\end{array}$ & $\begin{array}{c}105.11 \\
\pm 1.6\end{array}$ & $\begin{array}{l}167.42 \\
\pm 4.9^{1 a}\end{array}$ & $\begin{array}{l}217.52 \\
\pm 2.0^{l b}\end{array}$ & $\begin{array}{c}108.34 \\
\pm 5.6\end{array}$ & $\begin{array}{l}139.06 \\
\pm 5.8^{1 a}\end{array}$ & $\begin{array}{l}166.87 \\
\pm 7.9^{1 b}\end{array}$ \\
\hline ALAT (U/l) & $\begin{array}{l}18.27 \\
\pm 2.2\end{array}$ & $\begin{array}{l}19.50 \\
\pm 2.1\end{array}$ & $\begin{array}{l}21.44 \\
\pm 1.6\end{array}$ & $\begin{array}{l}41.14 \\
\pm 1.7^{1 a}\end{array}$ & $\begin{array}{l}54.57 \\
\pm 3.2^{l b}\end{array}$ & $\begin{array}{l}22.81 \\
\pm 2.7\end{array}$ & $\begin{array}{l}43.56 \\
\pm 3.5^{1 a}\end{array}$ & $\begin{array}{l}58.91 \\
\pm 1.4^{1 b}\end{array}$ \\
\hline LDH (U/l) & $\begin{array}{c}654.54 \\
\pm 21.8\end{array}$ & $\begin{array}{l}1678.50 \\
\pm 27.5^{1 b}\end{array}$ & $\begin{array}{c}817.77 \\
\pm 23.0\end{array}$ & $\begin{array}{l}2028.14 \\
\pm 20.1^{l b}\end{array}$ & $\begin{array}{l}1975.57 \\
\pm 19.2^{1 b}\end{array}$ & $\begin{array}{c}828.15 \\
\pm 21.1\end{array}$ & $\begin{array}{l}2196.48 \\
\pm 18.3^{l b}\end{array}$ & $\begin{array}{l}2172.42 \\
\pm 17.6^{l b}\end{array}$ \\
\hline CK(U/l) & $\begin{array}{c}112.00 \\
\pm 1.8\end{array}$ & $\begin{array}{c}160.90 \\
\pm 4.8\end{array}$ & $\begin{array}{c}171.88 \\
\pm 8.8\end{array}$ & $\begin{array}{l}331.00 \\
\pm 5.2^{1 a}\end{array}$ & $\begin{array}{l}410.57 \\
\pm 3.0^{l b}\end{array}$ & $\begin{array}{c}148.37 \\
\pm 1.2\end{array}$ & $\begin{array}{c}191.87 \\
\pm 4.3\end{array}$ & $\begin{array}{l}263.28 \\
\pm 2.7^{1 a}\end{array}$ \\
\hline $\mathbf{A P}(\mathbf{U} / \mathbf{l})$ & $\begin{array}{c}127.63 \\
\pm 4.8\end{array}$ & $\begin{array}{c}174.50 \\
\pm 4.5\end{array}$ & $\begin{array}{c}105.57 \\
\pm 3.0\end{array}$ & $\begin{array}{l}134.22 \\
\pm 5.1^{1 a}\end{array}$ & $\begin{array}{l}145.00 \\
\pm 3.2^{1 b}\end{array}$ & $\begin{array}{c}107.96 \\
\pm 3.9\end{array}$ & $\begin{array}{c}130.37 \\
\pm 4.0\end{array}$ & $\begin{array}{l}154.50 \\
\pm 2.7^{1 a}\end{array}$ \\
\hline GGT (U/l) & $\begin{array}{l}18.11 \\
\pm 4.5 \\
\end{array}$ & $\begin{array}{r}26.50 \\
\pm 3.4^{1 a} \\
\end{array}$ & $\begin{array}{l}15.60 \\
\pm 4.3 \\
\end{array}$ & $\begin{array}{l}34.71 \\
\pm 4.8^{1 a} \\
\end{array}$ & $\begin{array}{l}40.00 \\
\pm 2.3^{1 b} \\
\end{array}$ & $\begin{array}{l}13.92 \\
\pm 3.3 \\
\end{array}$ & $\begin{array}{r}26.34 \\
\pm 2.5^{1 a} \\
\end{array}$ & $\begin{array}{l}37.52 \\
\pm 1.3^{l b} \\
\end{array}$ \\
\hline
\end{tabular}

Legend: ${ }^{a} p<0.05 ;{ }^{b} p<0.01 ;{ }^{c} p<0.001 ; 1$-vs. control groups; $C$ - control group; SCK - with subclinical ketosis; $C K-$ with clinical ketosis

In cows exhibiting signs of clinical ketosis, blood ASAT, ALAT, LDH, CK, AP and GGT were very elevated both than control and SCK cows from the respective groups. In the groups of recently calved animals, blood enzymes were 217.52 $\pm 2.0 \mathrm{UI}(\mathrm{p}<0.01)$ for ASAT; $54.57 \pm 3.2 \mathrm{U} / 1(\mathrm{p}<0.01)$ for ALAT; $957.57 \pm 19.2 \mathrm{U} / 1$ ( $<0.01)$ for $\mathrm{LDH}$; $410.57 \pm 3.0 \mathrm{U} / 1(\mathrm{p}<0.01)$ for $\mathrm{CK} ; 145.0 \pm 3.2 \mathrm{U} / 1(\mathrm{p}<0.01)$ for AP and 40.0 $\pm 2.3 \mathrm{U} / 1(\mathrm{p}<0.01)$ for GGT. In group III

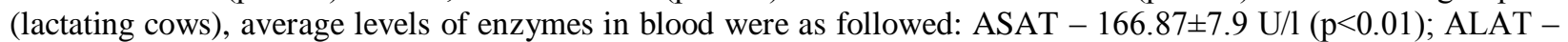
$58.91 \pm 1.4 \mathrm{U} / 1(\mathrm{p}<0.01) ; \mathrm{LDH}-2172.42 \pm 17.6 \mathrm{U} / 1(\mathrm{p}<0.01) ; \mathrm{CK}-263.28 \pm 2.7 \mathrm{U} / 1(\mathrm{p}<0.05) ;$ AP $-154.5 \pm 2.7 \mathrm{U} / 1$ $(\mathrm{p}<0.05)$ and GGT $-37.52 \pm 1.3 \mathrm{U} / 1(\mathrm{p}<0.01)($ Table 1$)$.

\section{Discussion:-}

Blood BHBA concentrations are an early marker for diagnosing SCK and CK in dairy animals (Oetzel, 2007; Duffield et al., 2009; McArt et al., 2013).

The results in pregnant cows from group I in the present study indicated that they were affected with SCK, not with CK as blood analysis did not show BHBA levels over $2.6 \mathrm{mmol} / \mathrm{l}$. Highly-producing cows suffer from subclinical and clinical ketosis during the postpartum period and at the time of intensive lactation (groups II and III) showing blood BHBA higher than $1.5 \mathrm{mmol} / \mathrm{l}$ (in SCK) and $>4 \mathrm{mmol} / \mathrm{l}$ (for CK). These results agree with those of other researchers (Seifi et al., 2011; González et al., 2011; McArt et al., 2013).High blood BHBA reflect the incomplete oxidation of non-esterified fatty acids (NEFA) in the Krebs cycle during NEB (Grummer, 1993). The rate of production of ketone bodies is proportional to the extent of lipolysis and fatty acids oxidation (Roche et al., 2013).

Blood enzymatic assays performed in cows with SCK and CK in different physiological states demonstrated highly statistically significant hyperenzymemias in comparison to control groups.

Blood plasma ASAT activity yields information about the extent of hepatocyte damage, as the enzyme is found in the cytosol (40\%) and mitochondria (60\%) of cell (Bobe et al., 2004; Gonzáles et al., 2011). As CK is accompanied by severe liver dystrophy, the activity if this enzyme is elevated, as confirmed by other authors (Pechova et al., 1997; Lubojacka et al., 2005). Detected ASAT concentrations were considerably higher in animals with clinical ketosis than in those suffering from the subclinical form, as also affirmed in other studies (Nogalski et al., 2012). 
ALAT is an enzyme specific for hepatocyte damage, found in the cytoplasm. Its increased plasma concentration is a marker of liver pathology. Increased activity of blood transaminases in our belief provides evidence that liver destructive changes were present in a major part of animals affected with ketosis and consequently, these enzymes are released from cell organelles into the circulation. A positive correlation was established between blood BHBA and ASAT in affected animals. In contrast to our findings, some authors (Rezapour and Taghinejad-Roudbaneh, 2011; Anoushepour et al., 2014), did not found out any significant changes in the activities of both liver enzymes.

High GGT level in blood is a diagnostic marker of hepatobiliary system disease (Grummer, 1993; Sahinduran et al., 2010; Djoković et al., 2013). In the present study, blood GGT was significantly elevated. Increased activity of GGT and ASAT is used as indicator of liver damage in ketotic cows, being proportional to the extent of histological changes. We established a positive relationship between blood GGT and ASAT, as well as between GGT and BHBA in the blood of cows with ketonaemia.

Increased LDH activity was detected in all three groups of cows with SCK and CK as compared to control groups. The high enzyme activity could be associated to cell damage of some parenchymal organs (liver, kidneys and hearth). It was points at muscle damage during the lactation period. Enzyme activities in blood should not be interpreted separately, but together, as in this study and other investigations (Peneva and Goranov, 1984; Yokus et al., 2006; Rezaeisaber et al., 2013). A positive correlation between blood NEFA and LDH and BHBA was found out in cows with ketonaemia, fatty liver dystrophy and high blood ASAT, ALAT and LDH (Yokus et al., 2006; Rezaeisaber et al., 2013), which is in line is values obtained by us in pregnant and lactating cows with ketosis.

The activity of blood creatine kinase was not altered in any of the three groups and was maintained within the reference range. The lower feed intake during the transitional period could lead to muscle damage, followed by increased activity of muscle enzymes (creatine kinase) (Gürgöze et al., 2009).

In serious liver damage associated with cholestasis, increased release of AP in the circulation from the biliary duct epithelium was reported (Simonov and Vlizlo, 2015). Blood AP, GGT and ASAT levels in cows with hyperketonemia were higher (Simonov and Vlizlo, 2015) similar to our findings.

\section{Conclusion:-}

In conclusion, SCK and CK in dairy cows could be detected on the basis of blood BHBA concentrations. Pregnant cows from group I were affected by SCK but not by CK (BHBA $<2.6 \mathrm{mmol} / \mathrm{l})$. During the postpartum period and intensive lactation, cows could suffer from both forms of ketosis. Blood biochemical analysis of activities of ASAT, ALAT, LDH, AP, CK and GGT in cows with subclinical and clinical ketosis demonstrated various extent of statistically significant hyperenzymemias.

\section{References:-}

1. Anoushepour, A., Mottaghian, P. and Sakha, M. (2014): The comparison of some biochemical parameters in hyperketonemic and normal ewes. Eur. J. Exp. Biology, 4, (3), 83-87.

2. Asl, A.N., Nazifi, S., Ghasrodashti, A.R. andOlyaee,A. (2011): Prevalence of subclinical ketosis in dairy cattle in the south western Iran and detection of cut off point for NEFA and glucose concentrations for diagnosis of subclinical ketosis. Prev. Vet. Med., 100, 38-43.

3. Bobe, G., Young, J.W. and Beitz, D.C. (2004): Invited review: pathology, etiology, prevention and treatment of fatty liver in dairy cows. J. Dairy Sci., 87, 3124.

4. Chapinal, N., Carson, M.E., Leblanc, S.J.,Leslie, K.E.,Godden, S., Capel, M., Santos, J.E. Overton, M.W. andDuffield,T.F. (2012): The association of serum metabolites in the transition period with milk production and early lactation reproductive performance. J. Dairy Sci., 95, 1301-1309.

5. Djoković, R., Kurćubić, V.,Ilić, Z.,Cincović, M., Petrović, M., Fratrić, N. andJašović,B. (2013): Evaluation of metabolic status in Simmental dairy cows during late pregnancy and early lactation. Vet. Arhiv, 83, (6), 593602.

6. Duffield, T.F., Lissemore, K.D.,McBride, B.W. andLeslie,K.E. (2009): Impact of hyperketonemia in early lactation dairy cows on health and production. J Dairy Sci., 92, 571-580. 
7. González, F.D., Muiño, R., Pereira, V., Campos, R. and Benedito,J.L. (2011): Relationship among blood indicators of lipomobilization and hepatic function during early lactation in high-yielding dairy cows. J. Dairy Sci., 12, 251-255.

8. Grummer, R.R. (1993): Etiology of lipid-related metabolic disorders in periparturient dairy cows. J. Dairy Sci., $76,12$.

9. Gürgöze, S.Y., Zonturlu, A.K.,Özyurtlu, N. andi்çen,H.(2009): Investigation of some biochemical parameters and mineral substance during pregnancy and postpartum period in Awassi ewes. Kafkas Univ. Vet. Fak. Derg. $15,(6), 957-963$.

10. Herdt, T.H. (2000): Ruminant adaptation to negative energy balance. Influences on the etiology of ketosis and fatty liver. Vet. Clin. North Am. Food Anim. Pract., 16, 215-230.

11. Joksimović, M. andDavidović,V. (2012): Changes in white blood pictures and some biochemical parameters of dairy cows in peripartum period and early lactation. Mljekarstvo, 62, (2), 151-158.

12. Kauppinen, K. (1983): Correlation of whole blood concentrations of acetoacetate, beta-hydroxybutyrate, glucose and milk yield in dairy cows as studied under field conditions. Acta Vet. Scand., 24, 337-348.

13. Kelton, D.F., Lissemore, K.D. andMartin,R.E. (1998): Recommendations for recording and calculating the incidence of selected clinical diseases of dairy cattle. J. Dairy Sci., 81, 2502-2509.

14. Lubojacka, V., Pechova, A., Dvorak, R., Drastich, P., Kummer, V. and Poul, J. (2005): Liver steatosis following supplementation with fat in dairy cows diets. Acta Vet. Brno, 74, 217-224.

15. Marutsova, V. (2015): Changes in blood enzyme activities in ewes with ketosis. International J. of Adv. Res., 3, (6), 462-473.

16. McArt, J.A., Nydam, D.V. andOetzel, G.R. (2012): Epidemiology of subclinical ketosis in early lactation dairy cattle. J. Dairy Sci., 95, 5056-5066.

17. McArt, J.A., Nydam, D.V. and Oetzel, G.R. (2013): Dry period and parturient predictors of early lactation hyperketonemia in dairy cattle. J. Dairy Sci., 96, 198-209.

18. Nogalski, Z., Wroński, M., Sobczuk-Szul, M., Mochol, M. and Pogorzelska, P. (2012): The effect of body energy reserve mobilization on the fatty acid profile of milk in high-yielding cows. Asian-Austral. J. Anim. Sci., 25, (12), 1712-1720.

19. Oetzel, G.R. (2007): Herd-level ketosis - diagnosis and risk factors. Preconf. Sem. 7C: Dairy herd problem investigation strategies: Transition cow troubl. Am. Assoc. Bov. Pract, 40th Ann. Conf., Sept. 19, 2007 - Vancouver, $\mathrm{BC}$, Canada.

20. Pechova, A., Liek, J. and Halouzka,R. (1997): Diagnosis and control of the development of hepatic steatosis in dairy cows in the periparturient period. Acta Vet. Brno, 66, 235-243.

21. Peneva, I.and Goranov,K.H. (1984): Changes in the serum enzymes and clinical and clinic-biochemical indices of cows with subclinical ketosis. Vet. Med. Nauki, 21, 28-36.

22. Rezaeisaber, A.,Abdili, D., Noii, F.,Khanzadeh, J., Dehghan, H. and Akhondi,F. (2013): BHBA, NEFA and LDH have changed in fatty liver syndrome: An Abattoir-based study. Europ. J. Exper. Biology, 3, (1), 572-575.

23. Rezapour, A. and Taghinejad-Roudbaneh,M. (2011): Effects of restricted nutrition on biochemical parameters of liver function in pregnant Ghezel ewes. Sci. Res Essays, 6, 6695-6700.

24. Roche, J.R., Bell, A.W.,Overton, T.R. andLoor,J.J. (2013): Invited review: Nutritional management of the transition cow in the 21st century - a paradigm shift in thinking. Anim. Product. Sci., 53, (9), 1000-1023.

25. Sahinduran, S., Sezer, K.,Buyukoglu, T.,Albay, M.K. and Karakurum,M.C. (2010): Evaluation of some haematological and biochemical parameters before and after treatment in cows with ketosis and comparison of different treatment methods. J. Anim. Vet. Adv., 9, (2), 266-271.

26. Santschi, D.E., Moore, R.K. and Lefebvre,D.M. (2014): Prevalence of subclinical ketosis detected by near infrared analysis of BHB in DHI milk samples. Abstr. 1779, pres. at Am. Dairy Sci. Assoc. Meeting. Kansas City, MO.

27. Seifi, H.A., Leblanc, S.J.,Leslie,K.E. and Duffield,T.F. (2011): Metabolic predictors of postpartum disease and culling risk in dairy cattle. Vet. J., 188, 216-220.

28. Simonov, M. andVlizlo,V. (2015): Some blood markers of the functional state of liver in dairy cows with clinical ketosis. Bulg. J. Vet. Med., 18 (1), 74-82.

29. Suriyasathaporn, W., Heuer, C., Noordhuizen-Stassen, E.N. and Schukken,Y.H. (2000): Hyperketonemia and udder defense: a review. Vet. Res., 31, 397-412.

30. Suthar, V.S., Canelas-Raposo, J.,Deniz, A. and Heuwieser,W. (2013): Prevalence of subclinical ketosis and relationships with postpartum diseases in European dairy cows. J. Dairy Sci., 96, 2925-2938.

31. Wierda, A., Verhoeff, J. and Van Dijk,S. (1985): Effects of trampoline acetate and propylene glycol on pregnancy toxaemia in ewes. Vet. Rec., 116, 284-287.

32. Yokus, B., Cakmr, D.U., Kanay, Z., Gulten, T. and Uysal,E. (2006): Effects of seasonal and physiological variations on the serum chemistry, vitamins and thyroid hormone concentrations in sheep. J Vet Med A, 53, 271-276. 